\title{
Study of the activity of DNA polymerases $\beta$ and $\lambda$ using 5-formyluridine containing DNA substrates
}

\author{
E. A. Belousova, O. I. Lavrik \\ Novosibirsk Institute of Chemical Biology and Fundamental Medicine, Siberian Branch of the Russian Academy of Sciences \\ 8, Akademika Lavrentieva Ave., Novosibirsk, Russian Federation, 630090 \\ sheffield@ngs.ru
}

\begin{abstract}
Aims. To investigate the TLS-activity of human DNA polymerases $\beta$ and $\lambda$ (pols $\beta$ and $\lambda$ ) using 5-formyluridine (5-foU) containing DNA duplexes which are imitating the intermediates during replication of the leading DNA strand, and to study the influence of replication factors hRPA and hPCNA on this activity. Methods. The EMSA and the methods of enzyme's kinetics were used. Results. The capability of pols $\beta$ and $\lambda$ to catalyze DNA synthesis across 5-foU was investigated and the kinetic characteristics of this process in the presence and in the absence of protein factors hRPA and hPCNA were evaluated. Conclusions. It was shown that: (i) both proteins are able to catalyze TLS on used DNA substrates regardless of the reaction conditions, however, pol $\lambda$ was more accurate enzyme; (ii) hRPA can stimulate the efficacy of the nonmutagenic TLS catalyzed by pol $\lambda$ at the nucleotide incorporation directly opposite of 5-foU, at the same time it doesn't influence the incorporation efficacy if the damage displaced into the duplex; (iii) hPCNA doesn't influence the efficacy of TLS catalyzed by both enzymes.
\end{abstract}

Keywords: translesion synthesis, DNA polymerases $\beta$ and $\lambda$, 5-formyluridine.

Introduction. Nucleobases are chemically modified under the influence of environmental or organic factors. One of the major product of the thymine oxidation under UVA and ionized irradiation is 5-formyluridine, 5foU. The presence of 5-foU in the DNA doesn't lead to replication block of both DNA strands, however replicative DNA polymerases such as Klenow fragment, DNA polymerase alfa and gamma are able to incorporate any of all 4 dNTPs opposite 5-foU allowing for transition and transversions [1].

Translesion synthesis is one of the main strategies which is used by cell for replication of damaged DNA. It is known, that TLS is catalyzed by special DNA polymerases with majority them belonging to the $\mathrm{Y}$-family [2]. However, some data exists that indicate the role of $\mathrm{X}$-family DNA polymerases $\beta$ and $\lambda$ in TLS [3].

The set of in vitro experiments fulfilled using different damaged DNA substrates indicate that the efficacy of the nucleotide incorporation opposite the lesion and

\footnotetext{
(C) Institute of Molecular Biology and Genetics, NAS of Ukraine, 2012
}

the capability to catalyze DNA synthesis passing the lesion are varied for different DNA polymerases. Since TLS occurred directly in the replication complex, such replicative factors as PCNA and RPA can influence efficacy and accuracy of the TLS polymerases. Some experiments were already done but the result doesn't complete the full relations - in common, PCNA and RPA influence dependent from type of DNA lesion and specific DNA polymerase [4].

Therefore, here we attended to investigate the TLS activity of human DNA polymerases $\beta$ and $\lambda$ (pols $\beta$ and $\lambda$ ) using DNA duplexes with 5-foU in a template by kinetic approaches. As for DNA substrates we used primed DNA duplexes which imitate the TLS intermediates during the replication of the leading strand. Reactions were carried out in «high» and «low» levels fidelity of polymerization conditions that is in the presence of $\mathrm{Mg}^{2+}$ or $\mathrm{Mn}^{2+}$ ions, respectively.

Materials and methods. The following substances were used: BSA («New England Biolabs», USA); phage T4 polynucleotide kinase $(5000 \mathrm{U} / \mathrm{ml}$, «Biosan», Rus- 
sia); $\left[\gamma^{-32} \mathrm{P}\right]$ ATP with specific activity $5000 \mathrm{Ci} / \mathrm{mmol}$ (LBT ICBFM SB RAS); dNTP, reagents for electrophoresis and the main buffers components («Sigma», USA). Human recombinant pols $\beta$ and $\lambda$ were purified from $E s-$ cherichia coli BL21(DE3) RP cells as described in [5] and [6], correspondingly. Purified hRPA and hPCNA were kindly provided by I. O. Petruseva (LBCE ICBFM SB RAS). The following oligonucleotides were used: primer strand 5'-(d)CGGTATCCACCAGGTCTG-3' («GenSet», Switzerland); template strand 5'-(d)GGCT TCATCGTTGTCU ${ }^{5-{ }_{0}} \mathrm{CAGACCTGGTGGATACCG-}$ 3' (synthesized and kindly provided by T. S. Zatsepin, A. N. Belozersky Institute of Physico-Chemical Biology, Moscow State University).

Incorporation of the radioactive label into the 5'end of the primer was performed as described in [7].

Determination of the $K_{d}$ values for the DNA-protein complexes by EMSA was performed as described in [8].

$d N M P$ were incorporated into the 3 '-end of primer by DNA pols $\beta$ and $\lambda$. Reactions mixtures $(10 \mu \mathrm{l})$ contained $0.01 \mu \mathrm{M} 55^{\prime}-\left[{ }^{32} \mathrm{P}\right]$ labeled DNA substrate, $0.01 \mu \mathrm{M}$ pol, $5 \mu \mathrm{M}$ dNTP, $1 \mathrm{mM} \mathrm{MgCl}{ }_{2}$ or $\mathrm{MnCl}_{2}$ in TDB buffer (50 mM Tris-HCl, pH 8.0, $0.5 \mathrm{mM}$ DTT, $0.25 \mathrm{mg} / \mathrm{ml}$ BSA). All reactions were incubated at $37^{\circ} \mathrm{C}$ for $15 \mathrm{~min}$. The reactions were terminated by placement on ice. Reaction products were resolved by electrophoresis in $20 \%$ denaturant PAAG as described in [9] and subjected to autoradiography using Molecular Imager FX («BioRad», USA). Analysis was performed with the Quantity One («BioRad»).

The Michaelis constants and the maximal rates of DNA synthesis were determined as described in [10]. The data were fitted according to Michaelis-Menten kinetic equation.

The effect of $h R P A$ and $h P C N A$ on the polymerization reaction catalyzed by pols $\beta$ and $\lambda$ was studied as follow. The reaction mixtures $(10 \mu \mathrm{l})$ contained 0.01 $\mu \mathrm{M} 5$ 5'-[ $\left.{ }^{32} \mathrm{P}\right]$ labeled DNA substrate, $0.01 \mu \mathrm{M}$ pol, $0.5-$ $200 \mu \mathrm{M}$ dNTP, $1 \mathrm{mM} \mathrm{MgCl}{ }_{2}$ or $\mathrm{MnCl}_{2}$, hRPA or/and hPCNA in TDB buffer. The hRPA concentration was 5,10 or $20 \mathrm{nM}$ (in a ratio DNA:hRPA $=2: 1,1: 1,1: 2$ ). The hPCNA concentration was 50,100 or $200 \mathrm{nM}$ (in a ratio DNA:hPCNA = 1:5, 1:10, 1:20). The combined effect of hPCNA and hRPA was investigated by setting the $\mathrm{hPCNA}$ concentration at $100 \mathrm{nM}$ (in a ratio DNA :
$: \mathrm{hRPA}=2: 1,1: 1,1: 2)$. The reaction was performed at $37^{\circ} \mathrm{C}$ for $15 \mathrm{~min}$ and terminated by placement on ice. The reaction products were analyzed as described above.

Results and discussion. In the present work we studied the TLS activity of pols $\beta$ and $\lambda$ on DNA substrates mimicking the TLS intermediates during the replication of the leading strand. 5-foU located in the +1 position of the template strand with respect to the 3 '-end of the primer was used as a lesion.

To estimate the affinity of the selected DNA pols to DNA probes we carried out gel mobility shift assays. Data obtained indicate that introduction of the 5 -foU decrease the affinity of pol $\beta$ to DNA substrate containing single-stranded protruding 5 '-end $\left(\mathrm{K}_{\mathrm{d}} \sim 0.18 \mu \mathrm{M}\right.$ for undamaged DNA and $\sim 0.53 \mu \mathrm{M}$ for 5 -foU-DNA). The same modification of the DNA substrate result in decrease of $K_{d}$ value, i. e. to increase of the pol $\lambda$ affinity to the DNA used $(0.36 \mu \mathrm{M}$ for undamaged DNA and $\sim 0.18 \mu \mathrm{M}$ for 5-foU-DNA).

To determine which dNMP could be incorporated in the model system DNA synthesis was carried out in the presence of either one or all four dNTPs (Figure, $B$ ). It's easy to see that pol $\lambda$ was more accurate during DNA synthesis across 5-foU - the enzyme was able to catalyze the incorporation of dAMP which is the complement to the template dTMP. Insignificant incorporation of dGMP in the presence of $\mathrm{Mn}^{2+}$ ions (not more than $5 \%$ ) can be explained by «template slippage» mechanism clarified for pol $\lambda[11]$. In any case, kinetic characteristics of the incorporation of correct nucleotide characterized dATP as more effective substrate (for example, $\left.K_{\mathrm{m}}\left(\mathrm{dATP} / \mathrm{Mn}^{2+}\right) \sim 0.07 \mu \mathrm{M}, K_{\mathrm{m}}\left(\mathrm{dGTP} / \mathrm{Mn}^{2+}\right) \sim 0.15 \mu \mathrm{M}\right)$.

Pol $\beta$ proved itself as extremely inaccurate enzyme which is able to catalyze the incorporation of all dNTP opposite 5-foU (Figure, $A$ ). The incorporation of dGMP can be explained by «template slippage» mechanism [11], and the incorporation of dAMP and dTMP probably is the result of a low fidelity of pol $\beta$ [12]. In any case, the efficacy of the incorporation of correct dAMP was much higher with comparison of the incorporation efficacy of incorrect dGMP $\left(k_{\text {cal }} / K_{\mathrm{m}}\left(\mathrm{dATP} / \mathrm{Mg}^{2+}\right) \sim 0.051\right.$ $\left.\mu \mathrm{M}^{-1} \mathrm{~s}^{-1}, k_{\text {cal }} / K_{\mathrm{m}}\left(\mathrm{dGTP} / \mathrm{Mg}^{2+}\right) \sim 0.005 \mu \mathrm{M}^{-1} \mathrm{~s}^{-1}\right)$.

Thus, independently of the reaction conditions both enzymes are able to catalyze TLS process using described DNA. However, pol $\beta$ doesn't have the specificity at the passage of this type of damage. At the same time, 


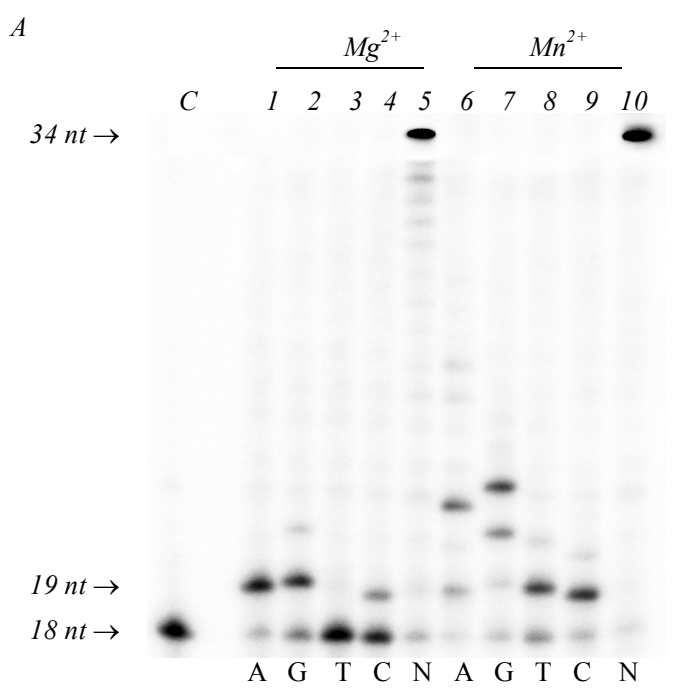

pol $\lambda$ is able to catalyze the incorporation of correct dAMP which is the complement to the original dTMP, thereby maintaining initial DNA sequence and doesn't force point mutations.

Since TLS constitutively associated with the replication machinery, replication and repair proteins could play a key role during this process. One of the potential TLS-participant during the replication on the leading strand is hRPA which contain subunits $\mathrm{p} 70, \mathrm{p} 32$ and p14 [13]. The main function of RPA include stabilization of DNA in a single-stranded conformation, positioning of the proteins at the nucleic-protein complexes, and activity stimulation of other protein factors.

Here the efficacy of DNA synthesis in the presence of hRPA was estimated by comparing the kinetic parameters for incorporation of correct dAMP or incorrect dGMP (Tables 1 and 2). As can be seen from presented results, the presence of hRPA doesn't influence the TLS efficacy catalyzed by pol $\beta$. Contrariwise, the efficacy of nonmutagenic TLS catalyzed by pol $\lambda$ was enhanced by hRPA by not affecting the dAMP incorporation and negatively affecting the dGMP incorporation (Table 2). Interestingly, the presence of hRPA doesn't influence on the activity of pol $\lambda$ during the next step of DNA synthesis, i. e. in the case when 5 -foU is located in the 0 position of the template strand with respect to the 3'-end of the primer (Table 2).

The next inherent component of the replication machinery is PCNA. First of all, PCNA is a processivity factor for the replicative DNA pols. Additionally, it participates in the coordination of protein-protein interac- tion in the replication complex [14]. Moreover, due to the majority of different proteins interacting with PCNA it can be suggested as a link between the replication and other cell's process such as TLS. Particularly, hPCNA has been proposed to coordinate switching from replicative DNA pols to specialized TLS enzymes [15]. Further, it has been demonstrated that PCNA physically interacts with pols $\beta$ and $\lambda[16,17]$.

The influence of hPCNA on TLS-activity of pols $\beta$ and $\lambda$ was estimated as described above. It turned out, that hPCNA doesn't influence the TLS efficacy of both pols using 5-foU-containing DNA substrates (Tables 1 and 2). These data are consistent with already published results: it was found, that PCNA increase the affinity of pol $\lambda$ to the 3'-end of the primer, stabilize the formation complex between the DNA substrate and enzyme, which allows to increase the processivity of DNA synthesis using undamaged DNA but doesn't change the enzyme affinity to dNTP and the efficacy of correct nucleotide incorporation [18]. At the same time, no alteration of the interplay between pol $\beta$ and damaged DNA in the presence of PCNA was obtained [4].

Absence of cumulative effect of hRPA and hPCNA on TLS-activity of pol $\beta$ across 5-foU was shown (Table 1). In contrast, combine presence of two protein factors lead to increase of accuracy of TLS catalyzed by DNA pol $\lambda$ mainly due to the increasing of the incorporation of correct dAMP (Table 2).

Therefore, hRPA has stimulated the efficacy of nonmutagenic TLS catalyzed by pol $\lambda$ at the incorporation of dNMP opposite to 5-foU and didn't have influence 
Table 1

The efficacy of dNTP incorporation by pol $\beta\left(k_{c a t} / K_{m}, \mu M^{-1} s^{-1}\right)$

\begin{tabular}{|c|c|c|c|c|c|c|c|c|}
\hline \multirow{2}{*}{$\mathrm{dNTP}$} & \multicolumn{4}{|c|}{$\mathrm{Mg}^{2+}$} & \multicolumn{4}{|c|}{$\mathrm{Mn}^{2+}$} \\
\hline & $\begin{array}{c}\text { - Replication } \\
\text { factor }\end{array}$ & $+\mathrm{hRPA}$ & + hPCNA & hRPA/hPCNA & $\begin{array}{c}\text { - Replication } \\
\text { factor }\end{array}$ & $+\mathrm{hRPA}$ & + hPCNA & $\mathrm{hRPA} / \mathrm{hPCNA}$ \\
\hline dATP & 0.051 & 0.055 & 0.049 & 0.052 & 12.6 & 12.9 & 12.1 & 12.9 \\
\hline dGTP & 0.005 & 0.006 & 0.006 & 0.006 & 0.31 & 0.33 & 0.29 & 0.35 \\
\hline $\begin{array}{l}\left(k_{\mathrm{cat}} / K_{\mathrm{m}}\right)_{\text {incor }} / \\
\left(k_{\mathrm{cat}} / K_{\mathrm{m}}\right)_{\mathrm{cor}} *\end{array}$ & 0.101 & 0.099 & 0.119 & 0.108 & 0.024 & 0.026 & 0.024 & 0.027 \\
\hline
\end{tabular}

The values shown were obtained under the conditions when replication factors were present at the maximal concentrations; $*\left(k_{\text {cat }} / K_{\mathrm{m}}\right)_{\text {incor }} /\left(k_{\text {cat }} / K_{\mathrm{m}}\right)_{\text {cor }}$ values in the presence or absence of replicaton factors. Note: the results are presented as the average value of three independent experiments.

Table 2

The efficacy of dNTP incorporation by pol $\lambda$ in the presence of $\mathrm{Mn}^{2+}$ ions

\begin{tabular}{|c|c|c|c|c|c|c|}
\hline dNTP & - Replication factor & + hRPA & + hPCNA & $\mathrm{hRPA} / \mathrm{hPCNA}$ & - Replication factor** & $+\mathrm{hRPA}^{* *}$ \\
\hline dATP & 0.111 & 0.108 & 0.116 & 0.401 & - & - \\
\hline dGTP & 0.302 & 0.008 & 0.287 & 0.365 & 0.137 & 0.126 \\
\hline $\begin{array}{c}\left(k_{\mathrm{cat}} / K_{\mathrm{m}}\right)_{\text {incor }} / \\
\left(k_{\mathrm{cat}} / K_{\mathrm{m}}\right)_{\mathrm{cor}}{ }^{*}\end{array}$ & 2.72 & 0.08 & 2.47 & 0.91 & - & - \\
\hline
\end{tabular}

The values shown were obtained under the conditions when replication factors were present at the maximal concentrations; $*\left(k_{\text {cat }} / K_{\mathrm{m}}\right)_{\text {incor }} /\left(k_{\text {cat }} / K_{\mathrm{m}}\right)_{\text {cor }}$ values in the presence or absence of replicaton factors; $* *$ the efficacy constant values for DNA synthesis using DNA with +1 primer length. Note: the results are presented as the average value of three independent experiments. Standard error was estimated as $10 \%$.

on the reaction if the synthesis starts from the 0 position relative to the damage.

Combined effect of hRPA and hPCNA analogously increase the accuracy of TLS across 5-foU catalyzed by pol $\lambda$ mainly due to the increasing of the incorporation of correct dNMP.

Basically, obtained results are in accordance with the published data. Indeed, it was shown using 5'-extended DNA substrates that TLS-activity of pol $\lambda$ across oxidative damages can be modulated by hRPA [4, 19-21]. At the same time, hRPA didn't display any effect on the TLS-capacity of pol $\beta$ across oxidative damages [4].

Combining the obtained results with published data it can be conclude, that pol $\lambda$ plays an important role in TLS across 5-foU during genomic replication on the leading strand.

Acknowledgements. This work was supported by a grant from the Russian Foundation for Basic Research (N12-04-00178-a).

\section{Є. А. Белоусова, О. І. Лаврик}

Активність ДНК-полімераз $\beta$ і $\lambda$ при синтезі ДНК-субстратів, які містять 5-формілуридин

Резюме

Мета. Дослідити активність TLS ДНК-полімераз $\beta$ і $\lambda$ людини на ДНК-дуплексах, які містять 5-формілуридин (5-foU) та імітують інтермедіати реплікації лідируючого ланиюга геномної ДНК, а також вплив на неї реплікативних факторів $h R P A$ и hPCNA. Методи. «Затримка в гелі» (EMSA), ферментативна кінетика. Результати. Вивчено здатність ДНК-полімераз $\beta$ і $\lambda$ активувати синтез ДНК через 5-foU. Визначено кінетичні характеристики иього проиесу за відсутності та в присутності білкових факторів hRPA $i$ hPCNA. Висновки. Показано, що 1) обидва ферменти можуть вести TLS на використаних ДНК-субстратах незалежно від умов реакиії, однак ДНК-полімераза $\lambda$ виявилася точнішим ферментом; 2) hRPA стимулює ефективність немутагенного TLS, каталізованого ДНК-полімеразою $\lambda$, безпосередньо при вбудовуванні нуклеотиду навпроти 5-foU $і$ не діс на ефективність иього процесу у тому разі, коли пошкодження зсунуте в дуплексну частину ДНК; 3) hPCNA не впливає на ефективність $T L S$, каталізованого обома ферментами.

Ключові слова: синтез ДНК через пошкодження, ДНК-полімерази $\beta$ и $\lambda$, 5-формілуридин. 


\section{Е. А. Белоусова, О. И. Лаврик}

Активность ДНК-полимераз $\beta$ и $\lambda$ при синтезе ДНК-субстратов, содержащих 5-формилуридин

Резюме

Цель. Исследовать TLS-активность ДНК-полимераз $\beta$ и $\lambda$ человека на ДНК-дуплексах, содержаших 5-формилуридин (5-foU) и имитирующих интермедиать репликации лидирующей цепи геномной ДНК, а также влияние на нее репликативных факторов $h R P A$ и hPCNA. Методы. «Задержка в геле» (EMSA), ферментативная кинетика. Результаты. Изучена способность ДНК-полимераз $\beta$ и $\lambda$ катализировать синтез ДНК через 5-foU. Определены кинетические характеристики этого процесса в отсутствие и в присутствии белковых факторов hRPA и hPCNA. Выводы. Показано, что: 1) оба фермента способны вести TLS на использованных ДНК-субстратах независимо от условий реакции, однако ДНКполимераза $\lambda$ оказалась более точным ферментом; 2) hRPA стимулирует эффективность немутагенного TLS, катализируемого ДНК-полимеразой $\lambda$, непосредственно при встраивании нуклеотида напротив 5-foU и не влияет на эффективность этого прочесса в том случае, когда повреждение сдвинуто в дуплексную часть ДНК; 3) hPCNA не влияет на эффективность TLS, катализируемого обоими ферментами.

Ключевые слова: синтез ДНК через повреждение, ДНК-полимеразы $\beta$ и $\lambda$, 5-формилуридин.

\section{REFERENCES}

1. Bjelland S., Anensen H., Knaevelsrud I., Seeberg E. Cellular effects of 5-formyluracil in DNA // Mutat. Res.-2001.-486, N 2.-P. 147-154.

2. Ohmori H., Friedberg E. C., Fuchs R. P., Goodman M. F., Hanaoka F., Hinkle D., Kunkel T. A., Lawrence C. W., Livneh Z., Nohmi T., Prakash L., Prakash S., Todo T., Walker G. C., Wang $Z$., Woodgate R. The Y-family of DNA polymerases // Mol. Cell.-2001.-8, N 1.-P. 7-8.

3. Belousova E. A., Lavrik O. I. DNA polymerases beta and lamb$\mathrm{da}$, and their roles in the DNA replication and repair // Mol. Biol. (Moscow).-2010.-44, N 6.-P. 947-965.

4. Maga G., Villani G., Crespan E., Wimmer U., Ferrari E., Bertocci B., Hubscher U. 8-oxo-guanine bypass by human DNA polymerases in the presence of auxiliary proteins // Nature.-2007.447, N 7144.-P. 606-608.

5. Braithwaite E. K., Prasad R., Shock D. D., Hou E. W., Beard W. A., Wilson $S$. H. DNA polymerase lambda mediates a back-up base excision repair activity in extracts of mouse embryonic fibroblasts // J. Biol. Chem.-2005.-280, N 18.-P. 18469-18475.

6. Drachkova I. A., Petruseva I. O., Safronov I. V., Zakharenko A. L., Shishkin G. V., Lavrik O. I., Khodyreva S. N. Reagents for modification of protein-nucleic acids complexes. II. Site-specific photomodification of DNA-polymerase beta complexes with primers elongated by the dCTP exo-N-substituted arylazido derivatives // Bioorg. Khim.-2001.-27, N 3.-P. 197-204.

7. Mazin A. Label's introducing into DNA // Methods of molecular genetics and gene engineering] / Ed. R. I. Salganik.-Novosibirsk: Science SBRAS, 1990.-P. 25-26.
8. Belousova E. A., Maga G., Fan Y., Kubareva E. A., Romanova E. A., Lebedeva N. A., Oretskaya T. S., Lavrik O. I. DNA polymerases beta and lambda bypass thymine glycol in gapped DNA structures // Biochemistry.-2010.-49, N 22.-P. 4695-4704.

9. Kraev A. Sequencing gels // Methods of molecular genetics and gene engineering / Ed. R. I. Salganik.-Novosibirsk: Science SBRAS, 1990.-P. 145-153.

10. Shtygasheva A. A., Belousova E. A., Rechkunova N. I., Lebedeva N. A., Lavrik O. I. DNA polymerases beta and lambda as potential participants of TLS during genomic DNA replication on the lagging strand // Biochemistry (Moscow).-2008.-73, N 11.P. 1207-1213.

11. Blanca G., Villani G., Shevelev I., Ramadan K., Spadari S., Hubscher U., Maga G. Human DNA polymerases lambda and beta show different efficiencies of translesion DNA synthesis past abasic sites and alternative mechanisms for frameshift generation // Biochemistry.-2004.-43, N 36.-P. 11605-11615.

12. Kunkel T. A., Alexander P. S. The base substitution fidelity of eukaryotic DNA polymerases. Mispairing frequencies, site preferences, insertion preferences, and base substitution by dislocation // J. Biol. Chem.-1986.-261, N 1.-P. 160-166.

13. Fanning E., Klimovich $V$., Nager A. R. A dynamic model for replication protein A (RPA) function in DNA processing pathways // Nucleic Acids Res.-2006.-34, N 15.-P. 4126-4137.

14. Maga G., Hubscher $U$. Proliferating cell nuclear antigen (PCNA): a dancer with many partners // J. Cell Sci.-2003.-116, Pt 15.P. 3051-3060.

15. Budzowska M., Kanaar R. Mechanisms of dealing with DNA damage-induced replication problems // Cell Biochem. Biophys.2009.-53, N 1.-P. 17-31.

16. Kedar P. S., Kim S. J., Robertson A., Hou E., Prasad R., Horton $J$. K., Wilson S. H. Direct interaction between mammalian DNA polymerase beta and proliferating cell nuclear antigen // J. Biol. Chem.-2002.-277, N 34.-P. 31115-31123.

17. Shimazaki N., Yazaki T., Kubota T., Sato A., Nakamura A., Kurei $S$., Toji $S$., Tamai K., Koiwai $O$. DNA polymerase lambda directly binds to proliferating cell nuclear antigen through its confined C-terminal region // Genes Cells.-2005.-10, N 7.-P. 705715 .

18. Maga G., Villani G., Ramadan K., Shevelev I., Tanguy Le Gac N., Blanco L., Blanca G., Spadari S., Hubscher U. Human DNA polymerase lambda functionally and physically interacts with proliferating cell nuclear antigen in normal and translesion DNA synthesis // J. Biol. Chem.-2002.-277, N 50.-P. 48434-48440.

19. Maga G., Shevelev I., Villani G., Spadari S., Hubscher U. Human replication protein A can suppress the intrinsic in vitro mutator phenotype of human DNA polymerase lambda // Nucleic Acids Res.-2006.-34, N 5.-P. 1405-1415.

20. Crespan E., Hubscher U., Maga G. Error-free bypass of 2-hydroxyadenine by human DNA polymerase lambda with Proliferating Cell Nuclear Antigen and Replication Protein A in different sequence contexts // Nucleic Acids Res.-2007.-35, N 15.P. 5173-5181.

21. Krasikova Y. S., Belousova E. A., Lebedeva N. A., Pestryakov P. E., Lavrik O. I. Interaction between DNA Polymerase lambda and RPA during translesion synthesis // Biochemistry (Moscow).2008.-73, N 9.-P. 1042-1046. 